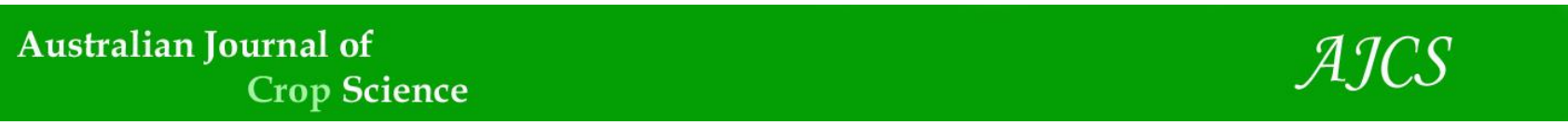

AJCS 14(09):1372-1378 (2020)

ISSN:1835-2707

doi: 10.21475/ajcs.20.14.09.p2167

\title{
Application of several green manures to produce organic cabbage (Brassica oleracea var. Capitata) and their influence on soil biological properties
}

\author{
Thatiany da Silva Bento ${ }^{1}$, Marco Antonio Camillo de Carvalho ${ }^{1,2}$, Oscar Mitsuo Yamashita ${ }^{2 *}$, Rivanildo \\ Dallacort $^{1,2}$, Ivone Vieira da Silva ${ }^{2}$, Ricardo Adriano Felito ${ }^{3}$, Dejânia Vieira de Araújo ${ }^{1}$ \\ ${ }^{1}$ Postgraduate Program in Environments and Production Systems, Mato Grosso State University, Tangará da Serra, \\ MT, Brazil \\ ${ }^{2}$ Postgraduate Program in Amazonian Biodiversity and Agroecosystems, Mato Grosso State University, Alta Floresta, \\ MT, Brazil \\ ${ }^{3}$ Postgraduate Program in Agriculture. Paulista State University, Botucatu, SP, Brazil
}

\section{*Corresponding autor: yama@unemat.br}

\begin{abstract}
Green manure stands out in the organic vegetable production as complementary fertilizer alternative to organic compound incorporation, contributing to reduce production costs and improve soil physical, chemical and biological features. The aim of the current study is to assess green manure and spontaneous vegetation species in cropping systems focused on the organic cabbage production, as well as their influence on soil microbial community. The treatments consisted of green manures such as black velvet beans (Stizolobium aterrimum), Crotalaria spectabilis, jack beans (Canavalia ensiformis), pigeon peas (Cajanus cajan cv. lapar 43) and spontaneous vegetation (fallow) in two cropping systems (with and without incorporation of green manure plants). Evaluations of green manure, cabbage crop and soil microbial activity were carried out. Green manure: fresh and dry mass, nitrogen and accumulated nitrogen content; Cabbage culture: horizontal and vertical diameter of the head, commercial and total mass; Microbial soil activity: soil microbial biomass carbon, soil basal respiration and metabolic quotient. For fresh and dry mass, jack beans and pigeons pea presented higher values, indicating good performance of these materials. For both, nitrogen content and accumulated nitrogen, the jack beans were stood. Regarding cabbage culture, the spontaneous vegetation decreased the horizontal diameter of the head when the incorporation did not occur. As for the commercial mass, for jack beans the cultivation with incorporation was superior. When the incorporation of the covering plants occurred, the crotalaria spectabilis produced less commercial mass and total head mass. Still in relation to total head mass, jack beans and spontaneous vegetation had lower mass when no incorporation occurred. As to soil microbial biomass carbon the spontaneous vegetation presented higher value, differing only from black velvet beans. The use of jack beans as a cover crop associated with the incorporation system was shown to be promising for the production of cabbage.
\end{abstract}

Keywords: Cajanus cajan; Canavalia ensiformis; cropping systems; Crotalaria spectabilis; nitrogen content; Stizolobium aterrimum; spontaneous vegetation; weeds

Abbreviations: BSR_basal soil respiration (BSR), MBC_microbial biomass carbon (MBC), LaSeM_Laboratory of Seed Technology and Matology, UNEMAT_Mato Grosso State University, LASAF_Soil and Leaf Analysis Laboratory.

Introduction

Cabbage (Brassica oleracea var. Capitata) is an herbaceous biennial plant mainly cultivated by small producers. In addition, its production has great economic and social importance in Brazil (Giordano, 2019), since it has high nutritive and commercial value and presents high soil nutrient-extraction capacity (Dechassa and Schenk, 2004; Easmin et al., 2009).

According to Dash et al. (2014), the increased demand of consumers for quality and chemical-free food, as well as the pursuit of an environmentally sustainable agriculture, boosted the development of organic food production. Such production system shows concern about land use and consumer's health. In addition, it enables farmers to live healthier lives and even to obtain better financial conditions through new market niches (Hasan and Solaiman, 2012). Using different soil covers and planting seedlings in the decaying residues of such covers is a promising vegetable cultivation method (Kumar et al., 2016). Besides improving the agronomic indicators, keeping residues on the soil helps maintaining its humidity for longer periods, decreases irrigation cost, minimizes the amount of mineral fertilizer due to nutrient cycling and provides other benefits such as controlling erosion processes and some invasive plants (Torres et al., 2015; Ferrarini et al., 2018).

The assessment of green manure systems is important because it expands the comprehension of environmental issues regarding combined production systems, supporting 
farmers' identification of hot spots and of better management practices (Santos et al., 2018). Nemecek et al. (2015) comment on the importance of studies on the environmental impacts of rotating green manure with the main crop on yield and soil quality in organic growing areas. McGuire (2016) and Miyasawa et al. (2011) pointed towards an expressive lettuce production increase after applying green manure without straw incorporation to the soil. In addition, they recorded $50 \%$ reduction in the use of organic compounds, which helped reducing costs and manpower demands.

Spontaneous vegetation consists of allowing the natural flora to develop between the rows and/or the rows of crops, during the winter period or throughout the year and consequently, the spontaneous vegetation can be chosen as a trade-off without cost for the crops can improve soil properties, limit mechanical work and maintain production (Kazakou et al., 2016).Sousa et al. (2016) verified that legumes and spontaneous vegetation had similar $\mathrm{C}$ concentration. However, the jack bean accumulated more biomass than hyacinth bean and spontaneous vegetation, which were similar to each other. They also comment that this result can be attributed not only to the adaptability of the jack bean to the soil and climatic conditions of the region, but also its fast vegetative growth, while hyacinth bean presented a longer life cycle and slower initial growth, resulting in less biomass accumulation in the same culture time period. The biomass production of the spontaneous vegetation was similar to the hyacinth bean, but presented a higher C: $\mathrm{N}$ ratio and a smaller amount of accumulated $\mathrm{N}$. According to Drobnik et al. (2018), soil quality can be measured through indicators, which are attributes able to measure or reflect the environmental status or the ecosystem sustainability condition. Microorganisms in the soil are responsible for essential processes taking place in such medium; they act in the genesis and decomposition of organic residues, in nutrient cycling, in organic matter formation and in the bioremediation of areas contaminated by pollutants and agrochemicals. Determining the basal soil respiration (BSR) and the microbial biomass carbon (MBC) in the soil allows analyzing soil biological properties and using them as environmental quality indicators.

Therefore, the aim of the current study was to assess the effect of using green manures, with and without incorporation of green manures of plants to the soil, on organic cabbage production and its implications to microbial activity in the soil.

\section{Results and discussion}

\section{Green manure and spontaneous vegetation}

The survey about spontaneous vegetation recorded the following plants and their respective frequencies: $7.6 \%$ Benghal dayflower (Commelina benghalensis), 34.8\% signal grass (Brachiaria decumbens), 18.2\% zigzag joint vetch (Aeschynomene rudis), $10.6 \%$ Indian goose grass (Eleusine indica), $18.2 \%$ green amaranth (Amaranthus viridis), and $10.4 \%$ stinking weed (Senna occidentalis).

The highest fresh mass production among plants subjected to green manure was recorded for jack beans (32.6 Mg ha ${ }^{-1}$ ) and pigeon peas (29.8 Mg ha ${ }^{-1}$ ) being respectively 4.46 and 4.08 times greater than spontaneous vegetation ( $7.3 \mathrm{Mg}$ ha $\left.{ }^{1}\right)$ (Table 1). The highest mean dry masses were recorded for pigeon peas, jack beans and crotalaria spectabilis. The lowest dry mass among legumes was recorded for black velvet beans. It happened because its cycle is longer than that of other green manures; thus, it had not reached its maximum mass accumulation at management time. Such accumulation would happen in the full bloom phase, fact that should be taken into consideration if one wants to use the aforementioned species as green manure.

The time that green manure remains in the field is essential to help planning agricultural activities. Teodoro et al. (2011) studied species such as gray velvet beans (Mucuna nivea), black velvet beans (Mucuna aterrima), Lablab bean (Dolichos lablab), jack beans (Canavalia ensiformis), crotalaria juncea, crotalaria spectabilis, and pigeon peas (Cajanus cajan); they found different cycle durations between the investigated species. Crotalaria juncea, crotalaria spectabilis and pigeon peas presented smaller cycles than the other species. According to the aforementioned authors, their results favor the insertion of these green manures in crop systems involving crop rotation and succession. Lablab beans, gray velvet beans and black velvet beans presented longer cycles, fact that could make their selection to form crop rotation and succession systems impossible, since these species require longer permanence time in the cultivation field. However, such longer permanence time is often not interesting to farmers because it leads to low field optimization.

Cavalcante et al. (2012) investigated biomass production and nutrient extraction in cover crops and recorded 16.2 and 3.0 $\mathrm{Mg} \mathrm{ha}^{-1} ; 30.2$ and $4.2 \mathrm{Mg} \mathrm{ha}^{-1} ; 19.0$ and $2.5 \mathrm{Mg} \mathrm{ha}^{-1} ; 16.5$ and 4.0 $\mathrm{Mg} \mathrm{ha}{ }^{-1}$; and 35.5 and $7.2 \mathrm{Mg} \mathrm{ha}^{-1}$ fresh mass and dry mass in jack beans, black velvet beans, crotalaria spectabilis, pigeon peas, and spontaneous vegetation handled, respectively, at ages 92, 100, 78, 92 and 104 days. Yield differences between the current study and the literature resulted from the way green manures responded to soil moisture and fertility conditions, as well as to temperature, to solar radiation and photoperiod in the site, to cropgrowing season, and to the time plants remained in the field. The highest nitrogen content was recorded for jack bean biomass, whereas the lowest content was found in the spontaneous vegetation biomass, which did not differ from pigeon peas, only. The lowest $N$ content found in spontaneous vegetation resulted from the fact that such vegetation mainly comprised grasses, as well as that these plants do not efficiently perform symbiotic $\mathrm{N}$ fixation as legumes do. Cavalcante et al. (2012) found different N contents just between green manure $\left(13 \mathrm{~g} \mathrm{~kg}^{-1}\right)$ and spontaneous vegetation (from 22.0 to $30.2 \mathrm{~g} \mathrm{~kg}^{-1}$ ). The selection of efficient biological nitrogen fixation species is extremely important to agricultural systems, since the association between these plant species and bacteria is the main responsible for the input of combined $\mathrm{N}$ in the environment (Vincent et al., 2018).

The nitrogen made available to the subsequent plants through green manure biomass decomposition is of foremost importance, since it is necessary applying $150 \mathrm{~kg}$ $\mathrm{ha}^{-1} \mathrm{~N}$ to cabbage crops according to recommendations by Fontes (1999). Table 1. shows that jack beans, crotalaria and pigeon peas recorded 218.9, 129.8 and $136.6 \mathrm{~kg} \mathrm{ha}^{-1} \mathrm{~N}$ accumulation, respectively, fact that makes it possible totally, or partially, replacing nitrogen fertilization. Accordingly Myint et al. (2010), assessed the impact of the green manures used in pre-cultivation processes, in association with different nitrogen levels in organic compounds, on cabbage and sweet corn yield in succession 
crops from 2007 to 2009 . They found that green manure increased the commercial cabbage yield by $19.2 \%$, as well as the commercial sweet corn yield by $4.5 \%$, when it was associated with compounds containing $3 \% \mathrm{~N}$.

Cavalcante et al. (2012) emphasized that, in order to assess plants efficiency as green manure, it is necessary investigating whether they produce large amounts of biomass and recycle large amounts of nutrients, so that the species can be recommended for green fertilization, cut and incorporated to the soil at early flowering.

\section{Characteristics of cabbage}

The analysis applied to cabbage crop variables did not show difference between green manures or any significant difference between biomass management systems in all features. There was interaction between green manure factors and biomass management systems concerning horizontal diameter, commercial and total head mass, commercial and total yield.

The commercial mass recorded in the present study was similar to that found by other authors such as Laczi et al. (2016), who studied the behavior of cabbage cultivars in organic production systems and recorded mean commercial head mass ranging from 1280 to $1560 \mathrm{~g}$.

The horizontal head diameter (Table 2) in the fallow (spontaneous vegetation) showed difference between crop systems; the biomass incorporation to the soil resulted in larger diameter. There was no difference between cover plants in both cropping systems. The lack of difference between cover plants (green manures) in the two cropping systems, despite the different biomass productions, may be related to the nutrient supplied by the organic substrate applied as manure at transplanting time; such substrate may have met the nutritional needs of the plants.

There was difference in the commercial and total head masses (Table 3 ) between green manures only in the cropping system with incorporation; the largest commercial and total head mass was recorded for crotalaria species, which just differed from the black velvet beans. Such difference may have happened due to the lower dry mass production recorded for black velvet beans, which were not ready to be handled because they had not reached their maximum vegetative development. Torres et al. (2015) also found higher cabbage yield in treatments producing higher dry mass. According to the aforementioned authors, these treatments allowed high nutrient extraction from the soil, besides enabling high biomass production.

Only crotalaria species showed difference in commercial head mass production between cropping systems; the incorporation system showed the best results (Table 3 ). Total head mass showed difference between systems in the crotalaria treatment; the largest mass was recorded for the incorporation system. With respect to the spontaneous vegetation treatment, the system without incorporation resulted in heavier heads. Such difference may be attributed to the fact that the incorporation of legume phytomass such as crotalaria, which undergoes rapid decomposition, increases the soil capacity of exchanging and retaining water, improves soil structure and positively affects crop performance. The decomposition process is associated with the chemical composition of the material; material transformation demands the following stages: first, significant biodegradation of most water-soluble compounds and polysaccharides; second, slow decrease in water-soluble phenols and hemicelluloses, and relative increase in lignin and protein contents (Guo et al., 2018).

Araújo et al. (2011) investigated nitrogen recovery in a soilplant system, in which green manure was applied to cabbage crops. They found that the treatment with jack bean straw presented the highest $\mathrm{N}$ recovery efficiency; it was even more efficient than crotalaria. Such result was attributed to the lower $\mathrm{C} / \mathrm{N}$ ratio found in crotalaria species, which enables faster mineralization and makes nutrients available to the successor crop. According to the aforementioned authors, the high $\mathrm{N}$ recovery efficiency resulted from the best asynchrony between successor-plant release and absorptive capacity. It may have happened between the cabbage plant and the crotalaria species used in the present study, since the crop transplantation process happened soon after the incorporation of green manures.

Torres et al. (2015) investigated soil covers applied to cabbage crop grown in Uberaba County - Brazil and recorded commercial cabbage head values ranging from 2.1 $\mathrm{kg}$ to $2.8 \mathrm{~kg}$; these values were higher than the ones found in the present study. Such difference may have happened because the aforementioned study adopted the conventional treatment with cattle manure and chemical fertilization.

\section{Soil microbial activity}

There was difference in the carbon content found in the soil microbial biomass between green manures (Table 4). The spontaneous vegetation recorded the highest carbon content values and just differed from pigeon peas; it may have happened because of the low dry mass produced by this leguminous species. Duarte et al. (2014) also recorded significant effect for soil microbial biomass carbon in management systems comprising different vegetation covers. Drobnik et al. (2018) set values to interpret soil quality bioindicators; soil microbial biomass carbon was one of the indicators. According to such interpretation, the value found in the treatment with pigeon peas was low; whereas the value recorded for the other legumes in the forest area was intermediate, and that of the spontaneous vegetation area was high.

The basal soil respiration and the metabolic quotient did not show differences between green manures and between cropping systems. In addition, there was no interaction between them (Table 4). The lack of response to these features may have happened because the area was already cultivated under organic production system; thus, the microbial population in the soil should be already balanced. According to Carrera et al. (2007), high $\mathrm{qCO}_{2}$ values indicate ecosystems subjected to some stress condition or disturbance.

Notaro et al. (2014) assessed the influence of different coffee-growing systems on soil biomass and microbial activity. They found that the high $\mathrm{qCO}_{2}$ values recorded in their study indicated that the microbial community maintenance may lead to greater energy expenditure, i.e., to stressing or disturbing situations, which may happen due to intensive soil management and to the frequent use of pesticides. Thus, microorganisms may need to consume more substrate in order to survive, although it was not observed in the present study, whose investigated area was cultivated under the organic production system. 
Table 1. Fresh and dry mass, nitrogen content and nitrogen accumulation in cover plants.

\begin{tabular}{|c|c|c|c|c|}
\hline Cover plants & $\begin{array}{l}\text { Fresh mass } \\
\left(\mathrm{Mg} \mathrm{ha}^{-1}\right)\end{array}$ & $\begin{array}{l}\text { Dry mass } \\
\left(\mathrm{Mg} \mathrm{ha}^{-1}\right)\end{array}$ & $\begin{array}{l}\text { Nitrogen content } \\
\left(\mathrm{g} \mathrm{kg}^{-1}\right)\end{array}$ & $\begin{array}{c}\mathrm{N} \text { accumulation } \\
\left(\mathrm{kg} \mathrm{ha}^{-1}\right)\end{array}$ \\
\hline$J B$ & $32.6 a$ & $6.8 \mathrm{a}$ & $32.1 \mathrm{a}$ & $218.9 a$ \\
\hline BVB & $18.9 \mathrm{c}$ & $2.3 \mathrm{~b}$ & $21.7 b$ & $50.4 \mathrm{c}$ \\
\hline CS & $22.8 \mathrm{bc}$ & $6.3 \mathrm{a}$ & $20.7 b$ & $129.8 b$ \\
\hline PP & $29.8 a b$ & $8.0 \mathrm{a}$ & $17.2 \mathrm{bc}$ & $136.6 \mathrm{~b}$ \\
\hline SV & $7.3 \mathrm{~d}$ & $2.1 \mathrm{~b}$ & $11.8 \mathrm{c}$ & $25.2 \mathrm{c}$ \\
\hline CV (\%) & 25.4 & 25.8 & 15.3 & 28.6 \\
\hline
\end{tabular}

Means followed by the same letters in the columns did not significantly differ from each other in the Tukey test, at $5 \%$ proba bility level. JB = jack beans, BVB $=$ black velvet beans, CS $=$ Crotalaria spectabilis, $\mathrm{PP}=$ pigeon peas, $\mathrm{SV}=$ spontaneous vegetation.

(A)

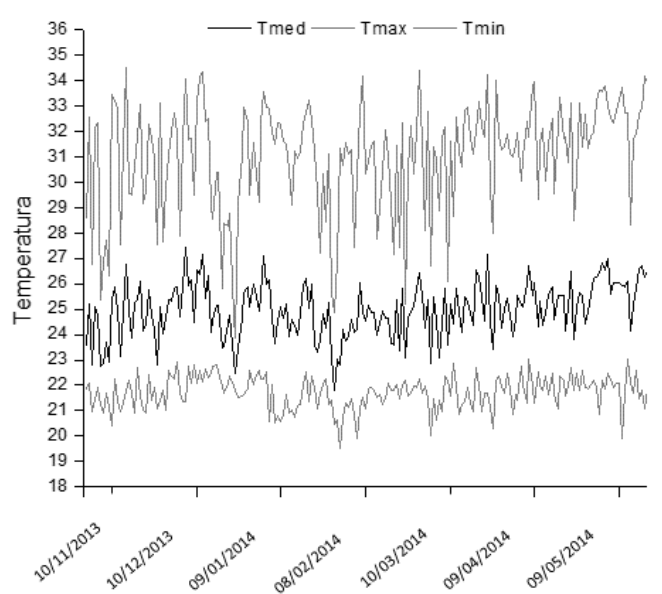

(B)

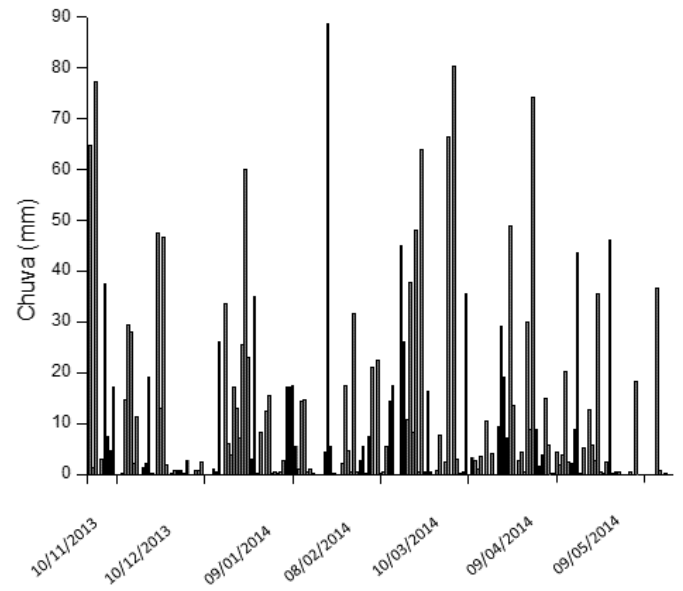

Fig 1. Climate data concerning mean temperature (Tmed), maximum temperature (Tmax), minimum temperature (Tmin) (A) and rainfall (B) during the research conduction period. Source: Unemat Climatological Station / Alta Floresta, MT, Brazil.

Table 2. Effect of the significant interaction between cropping systems and green manures on the horizontal diameter of cabbage "heads".

\begin{tabular}{lcc}
\hline \multirow{2}{*}{ Green manure (A) } & \multicolumn{2}{c}{ Cropping systems (S) } \\
\cline { 2 - 3 } & Without incorporation $(\mathrm{cm})$ & With incorporation $(\mathrm{cm})$ \\
\hline JB & $10.9 \mathrm{~A} \mathrm{a}$ & $11.5 \mathrm{~A} \mathrm{a}$ \\
BVB & $11.6 \mathrm{~A} \mathrm{a}$ & $11.3 \mathrm{~A} \mathrm{a}$ \\
CS & $11.4 \mathrm{~A} \mathrm{a}$ & $10.1 \mathrm{~A} \mathrm{a}$ \\
PP & $11.3 \mathrm{~A} \mathrm{a}$ & $10.7 \mathrm{~A} \mathrm{a}$ \\
SV & $9.7 \mathrm{~A} \mathrm{~b}$ & $11.5 \mathrm{~A} \mathrm{a}$ \\
\hline
\end{tabular}

DMS Tukey $(5 \%)-A($ System $)=1.90 ; \quad S($ Manure $)=1.39$

Means followed by the same uppercase letter in the column, and by the same lowercase letter on the line, did not differ from each other in the Tukey test, at $5 \%$ probability level. JB $=$ jack beans, $\mathrm{BVB}=$ black velvet beans, $\mathrm{CS}=$ Crotalaria spectabilis, $\mathrm{PP}=$ pigeon peas, and $\mathrm{SV}=$ spontaneous vegetation

Table 3. Effect of the significant interaction between cropping systems and green manures on variables such as commercial mass and total cabbage head.

\begin{tabular}{|c|c|c|c|c|}
\hline \multirow[b]{3}{*}{ Green manure } & \multicolumn{4}{|c|}{ Cropping system } \\
\hline & \multicolumn{2}{|c|}{ Commercial mass } & \multicolumn{2}{|c|}{ Total mass } \\
\hline & $\begin{array}{c}\text { Without incorporation } \\
(\mathrm{kg})\end{array}$ & $\begin{array}{c}\text { With incorporation } \\
(\mathrm{kg})\end{array}$ & $\begin{array}{c}\text { Without incorporation } \\
(\mathrm{kg})\end{array}$ & With incorporation (kg) \\
\hline$J B$ & $0.363 \mathrm{~A} \mathrm{~b}$ & $0.523 \mathrm{Aa}$ & $0.399 \mathrm{~A} \mathrm{~b}$ & $0.555 \mathrm{~A} \mathrm{a}$ \\
\hline BVB & $0.449 \mathrm{~A} \mathrm{a}$ & $0.388 \mathrm{AB}$ a & $0.518 \mathrm{~A} \mathrm{a}$ & $0.461 \mathrm{AB}$ a \\
\hline CS & $0.428 \mathrm{~A} \mathrm{a}$ & $0.302 \mathrm{~B}$ a & $0.459 \mathrm{~A} \mathrm{a}$ & $0.326 \mathrm{~B}$ a \\
\hline PP & $0.385 \mathrm{~A} \mathrm{a}$ & $0.398 \mathrm{AB}$ a & $0.416 \mathrm{~A} \mathrm{a}$ & $0.433 \mathrm{AB}$ a \\
\hline SV & $0.320 \mathrm{~A} \mathrm{a}$ & $0.497 \mathrm{AB}$ a & $0.310 \mathrm{~A} \mathrm{~b}$ & $0.488 \mathrm{AB}$ a \\
\hline
\end{tabular}

DMS Tukey (5\%)

$A(S)=205.7-S(A)=0.145$

$A(S)=208.8-S(A)=0.147$

Means followed by the same uppercase letter in the column, and by the same lowercase letter on the line, did not differ from each other in the Tukey test, at $5 \%$ probability level. JB $=$ jack beans, $\mathrm{BVB}=$ black velvet beans, $\mathrm{CS}=$ Crotalaria spectablis, $\mathrm{PP}=$ pigeon peas, and $\mathrm{SV}=$ spontaneous vegetation 
Table 4. Mean soil microbial biomass carbon ( $\mathrm{SMB}-\mathrm{C})$, basal soil respiration $\left(\mathrm{C}-\mathrm{CO}_{2}\right)$, and metabolic quotient $\left(\mathrm{q} \mathrm{CO}_{2}\right)$ determined in the $0-0.10 \mathrm{~m}$ depth layer in soil treated with different green manures.

\begin{tabular}{|c|c|c|c|}
\hline Treatments $(\mathrm{A})$ & $\begin{array}{l}\text { SMB-C } \\
\text { (mg C kg-1 soil) }\end{array}$ & $\begin{array}{l}\mathrm{C}-\mathrm{CO}_{2} \\
\left(\mathrm{mg} \mathrm{C}-\mathrm{CO}_{2}\right. \\
\left.\mathrm{kg}^{-1} \text { soil hour }{ }^{-1}\right)\end{array}$ & 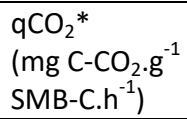 \\
\hline$J B$ & $234 a b$ & 0.2 & 1.1 \\
\hline BVB & 178 b & 0.3 & 1.6 \\
\hline CS & $310 a b$ & 0.3 & 1.2 \\
\hline $\mathrm{PP}$ & $301 a b$ & 0.2 & 1.1 \\
\hline SV & $434 \mathrm{a}$ & 0.1 & 0.5 \\
\hline Native forest & $217 a b$ & 0.1 & 1.4 \\
\hline F value & $2.9 *$ & $2.1 \mathrm{~ns}$ & $1.3 \mathrm{~ns}$ \\
\hline DMS Tukey 5\% & 225.6 & 0.1 & 1.2 \\
\hline \multicolumn{4}{|l|}{ Incorporation (I) } \\
\hline With & 286.8 & 0.2 & 1.2 \\
\hline Without & 270.9 & 0.2 & 1.1 \\
\hline F value & $0.1 \mathrm{~ns}$ & $0.9 \mathrm{~ns}$ & $0.0 \mathrm{~ns}$ \\
\hline DMS (Tukey 5\%) & 87.6 & 0.1 & 0.5 \\
\hline \multicolumn{4}{|l|}{ A x I interaction } \\
\hline F value & $0.9 \mathrm{~ns}$ & $0.9 \mathrm{~ns}$ & $0.7 \mathrm{~ns}$ \\
\hline CV (\%) & 29.5 & 24.4 & 21.3 \\
\hline
\end{tabular}

Means followed by the same letter did not statistically differ from each other in the Tukey test, at $5 \%$ probability level. ${ }^{* *}=$ significant at $1 \% ;{ }^{*}=s i g n i f i c a n t$ at $5 \%$; and $\mathrm{ns}=$ non-significant in the $\mathrm{F}$ test. ${ }^{*}$ Data transformed into the root of $x=\sqrt{x}+1 . \mathrm{JB}=$ jack beans, $\mathrm{BVB}=$ black velvet beans, $\mathrm{CS}=$ crotalaria spectablis, $\mathrm{PP}=$ pigeon peas, and $\mathrm{SV}=\mathrm{spontaneous}$ vegetation.

\section{Materials and methods}

\section{Experimental area}

The experiment was carried out in an organic production area located in Alta Floresta County - Brazil, at geographic coordinates 09 51' 42" S and 560 04' 07" W, altitude 283 meters. The climate in the region is rainy tropical (Am type according to Köppen). It presents well-defined seasons, severe drought and intense rainy season, temperature ranging from $18{ }^{\circ} \mathrm{C}$ to $40{ }^{\circ} \mathrm{C}$, and mean temperature $26^{\circ} \mathrm{C}$. The soil sample collected from the $0-0.20 \mathrm{~m}$ layer before the experiment showed the following results: $\mathrm{pH}$ in the water 6.4; $95.4 \mathrm{mg} \mathrm{dm}^{-3} \mathrm{P} ; 27.0 \mathrm{mg} \mathrm{dm}^{-3} \mathrm{~K} ; 3.4 \mathrm{cmol}_{\mathrm{c}} \mathrm{dm}^{-3} \mathrm{Ca} ; 0.6$ $\mathrm{cmol}_{\mathrm{c}} \mathrm{dm}^{-3} \mathrm{Mg} ; 0.0 \mathrm{cmol}_{\mathrm{c}} \mathrm{dm}^{-3} \mathrm{Al} ; 2.2 \mathrm{cmol}_{\mathrm{c}} \mathrm{dm}^{-3} \mathrm{H}+\mathrm{Al} ; 4.1$ $\mathrm{cmol}_{\mathrm{C}} \mathrm{dm}_{-3}$ base sum (BS); $6.3 \mathrm{cmol}_{\mathrm{C}} \mathrm{dm}^{-3}$ effective CTC; $65 \%$ base saturation (V\%); and $24.5 \mathrm{~g} \mathrm{dm}^{-3}$ organic matter.

\section{Conduction of study and experimental design}

The experiment followed a completely randomized block design at $5 \times 2$ factorial scheme with four repetitions. The treatments comprised by sowing of black velvet beans (Stizolobium aterrimum Piper \& Tracy), jack beans (Canavalia ensiformis (L.) DC.), crotalaria spectabilis (Crotalaria spectabilis Roth), pigeon peas (Cajanus cajan (L. Millsp.) cv. lapar 43) and spontaneous vegetation, with and without incorporation to the soil. The experimental plots presented dimension $1.2 \times 2.1 \mathrm{~m}$, with four replications.

Soil preparation for green manure sowing purposes was carried out at depth $0.15 \mathrm{~m}$, with the aid of a micro-tractor equipped with rotary tiller.

The locally purchased cabbage hybrid Astrus Plus from the company Seminis Vegetable Seeds was used in the current study. The green manures were sown on November $23^{\text {rd }}$, 2013; black velvet beans and jack beans were cultivated with $0.50 \mathrm{~m}$ spacing between rows and $0.20 \mathrm{~m}$ between plants, whereas crotalaria spectabilis and pigeon peas were cultivated with $0.50 \mathrm{~m}$ spacing between rows and $0.05 \mathrm{~m}$ between plants. The current study the next amounts of seeds were used: $15 \mathrm{~kg} \mathrm{ha}^{-1}$ crotalaria spectabilis, $60 \mathrm{~kg} \mathrm{ha}^{-1}$ pigeon peas, $80 \mathrm{~kg} \mathrm{ha}^{-1}$ black velvet beans, and $100 \mathrm{~kg} \mathrm{ha}^{-1}$ jack beans. Plots presenting spontaneous vegetation were not weeded until the cabbage was planted. Spontaneous vegetation and legumes at full flowering stage (except for black velvet beans, whose cycle happens later than the others) were grazed on February $23^{\text {rd }}, 2014$; they were incorporated to the soil with the aid of a micro-tractor equipped with rotary tiller in conventional cultivation treatments.

No irrigation was performed during the experiment application because it was implemented in the rainy season (Fig 1). Manual harvesting and weeding (with hoe) were carried out, whenever necessary, in order to help controlling spontaneous plant growth.

Before the cut of the spontaneous vegetation was carried out the phytosociological survey of the spontaneous plants present in the plots with this treatment, where a metallic frame with area of $0.25 \mathrm{~m}^{2}$ was thrown randomly within each plot. The species present in each sample were cut close to the soil, taken to the shed near the collection area where they were identified through specialized literature and, when necessary, referred to specialists. Five (5) samplings were collected in the experimental area.

Accordingly, $0.25 \mathrm{~m}^{2}$ samples per plot were collected in order to assess the green and dry masses of the green manures and of the spontaneous vegetation. These samples were weighed to find the green mass. A sub-sample was taken from the aforementioned sample in order to determine humidity values and, subsequently, to measure dry mass and nitrogen concentration. The surplus material was taken back to the experimental area in its respective plot.

The sub-samples were weighed and dried in forced-air oven at $65^{\circ} \mathrm{C}$, in order to determine the dry mass. The part of the sample used to assess nitrogen concentration was ground (Willey-type mill). The nitrogen concentration in the legumes and in the spontaneous vegetation was measured according to the methodology described by Bremner (1996). The amount of dry mass, as well as the nitrogen concentration in the legumes and in the spontaneous vegetation of each 
sample were used to calculate $\mathrm{N}$ accumulated in the dry mass; data were transformed into $\mathrm{kg} \mathrm{ha}^{-1}$.

On February $1^{\text {st }}, 2014$, the cabbage seeds were sown in polystyrene trays (128 cells) containing the substrate prepared for sowing purposes. The substrate used in the trays presented the following composition: $40 \%$ litter, $40 \%$ tanned poultry manure, and $20 \%$ carbonized rice straw.

The cabbage transplanting process took place 27 days later, using $0.60 \times 0.70 \mathrm{~m}$ spacing; the plot comprised 12 plants and the two central plants in each plot were considered the useful area.

The transplant fertilization adopted the same organic compound used to prepare the seedlings, at dose $200 \mathrm{~g}$ per pit. The compound presented the following natural matter composition: $5.6 \mathrm{mg} \mathrm{kg}^{-1}$ boron, $0.8 \%$ calcium, $19.3 \mathrm{mg} \mathrm{kg}^{-1}$ copper, $0.2 \%$ sulfur, $372.2 \mathrm{mg} \mathrm{kg}^{-1}$ iron, $0.3 \%$ phosphorus, $0.2 \%$ magnesium, $223 \mathrm{mg} \mathrm{kg}^{-1}$ manganese, $9.1 \%$ total organic matter (combustion), $8.1 \%$ total nitrogen, $0.3 \%$ potassium, $9.6 \%$ insoluble mineral residue, $2.4 \%$ soluble mineral residue, $12.0 \%$ total mineral residue, $70.6 \%$ humidity $\left(65^{\circ} \mathrm{C}\right)$, and $84 \mathrm{mg} \mathrm{kg}^{-1}$ zinc. On the other hand, the dry matter recorded $34.8 \%$ organic carbon, $24.0 \%$ total carbon (organic and mineral), 62.6\% compostable organic matter, $19.3 \%$ organic matter resistant to composting, $43.3 \%$ total organic matter (combustion), $4.3 \% \mathrm{C} / \mathrm{N}$ ratio (organic $\mathrm{C}$ and total $\mathrm{N}$ ), $2.9 \% \mathrm{C} / \mathrm{N}$ ratio (total $\mathrm{C}$ and total $\mathrm{N}$ ), $45.5 \%$ insoluble mineral residue, $11.5 \%$ soluble mineral residue, $57.2 \%$ total mineral residue, and $8.3 \%$ humidity $\left(105^{\circ} \mathrm{C}\right)$.

A natural insecticide based on neem (Azadirachta indica Juss.), known as Azamax, was used along with cow urine for pest control purposes throughout the experiment. The application was performed on a weekly basis, using $40 \mathrm{~mL}$ concentrated neem oil and $200 \mathrm{~mL}$ cow urine in each knapsack sprayer pump (20 L capacity).

The cabbage crop was assessed when plants showed maximum vegetative development, on $05 / 28^{\text {th }} / 2014$. The assessments were carried out at the Laboratory of Seed Technology and Weed Science (LaSeM - Laboratório de Tecnologia de Sementes e Matologia) in Mato Grosso State University (UNEMAT - Universidade do Estado de Mato Grosso), Alta Floresta Campus, MT, Brazil.

The plants were harvested by cutting their stems close to the ground. Cabbage heads were weighed in a semi analytical scale to find the total fresh "head" mass. Next, the outer leaves were removed to calculate the commercial "head" mass. The "head" height was measured based on the distance from the base (leaf insertion in the stem) to the apex of the leaves. A graduated scale was used to measure the diameter length at the center of the cabbage head in order to find the horizontal diameter. The hardness of the cabbage head was assessed in the FR-5120 digital penetrometer ( $3 \mathrm{~mm}$ tip).

\section{Laboratorial analysis}

C-organic and basal soil respiration analyses were performed at the Soil and Leaf Analysis Laboratory (LASAF) in Mato Grosso State University - UNEMAT, Alta Floresta Campus, MT, Brazil. Soil samples were collected (0-0.10 m deep) right after the cabbage was harvested. They were packed in plastic bags, protected from light, kept in a thermal box, and immediately taken to the laboratory. Basal respiration and metabolic quotient were set according to the methodology by Silva et al. (2007a), whereas the methodology by Silva et al. (2007b) was adopted to set the soil microbial biomass carbon. The microbial metabolic quotient $\left(\mathrm{qCO}_{2}\right)$ was calculated as the amount of $\mathrm{CO}_{2}-\mathrm{C}$ produced per unit microbial biomass carbon.

Soil samples were also collected in the native forest adjacent to the crop-growing area to help setting soil biological features in order to compare them to samples subjected to green manures and anthropic activity.

\section{Statistical analysis}

The values of the assessed features were subjected to analysis of variance in the Sisvar statistical software; means were compared in the Tukey test, at 5\% probability level.

\section{Conclusions}

The jack beans enabled higher $\mathrm{N}$ content and accumulation in the dry matter. The use of green manures did not affect the organic cabbage production. Cultivation with green manure incorporation enabled the highest commercialcabbage mass in the crotalaria treatment, whereas the highest total mass was recorded for treatments with crotalaria and spontaneous vegetation.

The herein applied treatments did not significantly change the microbial activity in the soil when they were compared to native forest and spontaneous vegetation.

\section{Acknowledgments}

To Coordination of Improvement of Higher Level Personnel (CAPES) for the grant of scholarship.

\section{References}

Araújo ES, Guerra JGM, Espindola JAA, Urquiaga S, Boddey RM, Martelleto LAP, Alves BJ (2011) Recovery in the soilnitrogen system derived from the green manure applied to the cabbage crop. Pesq Agrop Bras. 46(7):729-735.

Bremner JM (1996) Nitrogen-Total. In: Sparks DL (Ed) Methods of soil analysis. Chemical methods. Madison: Soil Science Society of America. p.1085-121.

Carrera LM, Buyer JS, Vinyard B, Abdul-Baki AA, Sikora LJ, Teasdale JR (2007) Effects of cover crops, compost, and manure amendments on soil microbial community structure in tomato production systems. Appl Soil Ecol. 37:247-255.

Cavalcante VS, Santos VR, Santos Neto AL, Santos MAL, Santos CG, Costa LC (2012) Biomass production and nutrient removal by plant cover. R Bras Eng Agríc Amb. 16(5):521-528.

Dash M, Samantaray A, Dash M (2014) Consumer's perception towards organic food products. Int J Eng Manag Res. 4(3):110-113.

Dechassa N, Schenk MK (2004) Exudation of organic anions by roots of cabbage, carrot, and potato as influenced by environmental factors and plant age. J PI Nutr Soil Sci. 167(5):623-629.

Drobnik T, Greiner L, Keller A, Grêt-Regamey A (2018) Soil quality indicators - From soil functions to ecosystem services. Ecol Indic. 94(1):151-169.

Easmin D, Islam MJ, Begum K (2009) Effect of different levels of nitrogen and mulching on the growth of Chinese cabbage. Progress Agric. 20:27-33. 
Ferrarini A, Bini C, Amaducci S (2018) Soil and ecosystem services: Current knowledge and evidences from Italian case studies. Appl Soil Ecol. 123:693-698.

Fontes PCR (1999) Alface. In: Ribeiro AC, Guimarães PTG, Alvarez VVH (ed) Recommendation for the use of correctives and fertilizers in Minas Gerais: 5th Approach. Commission on soil fertility in Minas Gerais, Viçosa. 5.

Giordano LD (2019) The present situation of cabbage breeding in Brazil. Avaliable in: http://agris.fao.org/agrissearch/search.do?recordID=JP9204156. Acess in: 21 sep. 2019.

Guo T, Zhang Q, Ai C, Liang G, Ping R, Zhou W (2018) Nitrogen enrichment regulates straw decomposition and its associated microbial community in a double-rice cropping system. Sci Rep. 8:1847.

Hasan MRH, Solaiman AHM (2012) Efficacy of organic and organic fertilizer on the growth of Brassica oleraceae $\mathrm{L}$. (cabbage). Int J Agric Crop Sci. 4(3):128-138.

Kazakou E, Fried G, Richarte J, Gimenez O, Violle C, Metay A (2016) A plant trait-based response-and-effect framework to assess vineyard inter-row soil management. Bot Lett. 163(4):373-388.

Kumar R, Singh S, Krishna KR, Anokhe A, Prakash NR (2016) Organic farming of vegetables: prospects and scenario. Gl J Biosci Biotech. 6(2):390-394.

Laczi E, Apahidean A, Luca E, Dumitraş A, Boancă P (2016) Headed Chinese cabbage growth and yield influenced by different manure types in organic farming system. Hort Sci. 43:42-49.

Miyazawa K, Takeda M, Murayama T, Watanabe K (2011) Combining pre-transplanting phosphorus application and green manure incorporation: a trial for reducing fertilizer input. Soil Sci PI Nut. 57(1):128-137.

Myint AK, Yamakawa T, Kajihara Y, Myint KKM, Zenmyo T (2010) Nitrogen dynamics in a paddy field fertilized with mineral and organic nitrogen sources. Am Eur J Agric Environ Sci. 7(2):221-231.
Nemecek T, Hayer F, Bonnin E, Carrouée B, Schneider A, Vivier C (2015) Designing eco-efficient crop rotations using life cycle assessment of crop combinations. Eur J Agron. 65:40-51.

Notaro KA, Medeiros EVD, Silva GP, Oliveira A, Moura PM (2014). Agroforestry systems, nutrients in litter and microbial activity in soils cultivated with coffee at high altitude. Sci Agric. 71(2):87-95.

Santos TL, Nunes ABA, Gionco V, Barros VS, Figueiredo MCB (2018) Cleaner fruit production with green manure: the case of Brazilian melons. J Clean Prod. 181:260-270.

Silva EE, Azevedo PHS, Delpolli H (2007a) Determination of basal respiration (RBS) and soil metabolic quotient $\left(\mathrm{qCO}_{2}\right)$. Com Técn 99, Embrapa, Brasília, 5.

Silva EE, Azevedo PHS, Delpolli H (2007b) Determination of soil microbial biomass carbon (BMS-C). Com Técn 98, Embrapa, Brasília, 6.

Sousa FF, Carmo DL, Carneiro JES, Urquiaga S, Santos RHS (2016) Legumes as green manure for common bean cultivated in two growing seasons at southeast Brazil. African J Agric Res. 11(49):4953-4958.

Teodoro RB, Oliveira FL, Silva DMN, Favero C, Quaresma MAL (2011) Agronomic aspects of leguminous to green fertilization in the cerrado of the high Jequitinhonha Valley. R Bras Ciênc Solo. 35(2):635-643.

McGuire A (2016) Using green manures in potato cropping systems. WSU Extension. 21(8):1-6.

Torres JLR, Araújo AS, Barreto AC, Silva Neto OF, Silva VR, Vieira DMS (2015) Development and productivity of cauliflower and cabbage influenced by soil mulching types Hort Bras. 33(3)510-514.

Vincent B, Jourand P, Juillot F, Ducousso M, Galiana A (2018) Biological in situ nitrogen fixation by an Acacia species reaches optimal rates on extremely contrasted soils. Eur J Soil Biol. 86(1): 52-62. 